\title{
20
}

\section{Indigenous title disputes: what they meant for the 2006 election}

Morgan Tuimaleali'ifano

The 2006 poll produced a mixed score-card for Fiji's customary chiefs. On the one hand, finding a place for Fiji's ruling dynasties at the centre of government remained a central concern for the re-elected Qarase government, not only because Fiji's Bose Levu Vakaturaga (Great Council of Chiefs) holds the critical swing votes in the Senate, but also because the newly elected prime minister felt obliged to bring top title-holders from all three of the country's confederacies into the post-election multiparty cabinet in order to guarantee ethnic Fijian support. On the other hand, as is shown in this chapter, chiefs have fared increasingly poorly at the last three elections, indicating a profound social transformation. What is the role of chiefly titles in determining success or failure at modern elections? Are there discernible trends in the performance of customary leaders at the polls?

This chapter explores the influence of chiefly rivalries on modern-day Fiji politics, particularly the performance of chiefs as traditional indigenous leaders at the 1999, 2001 and 2006 polls, and how these influenced the post-election formation of governments.

After more than a century of colonial structures, the hereditary chiefly hierarchy continues to exercise a major influence on the majority of indigenous Fijians and other citizens of Fiji. The colonially instituted Bose Levu Vakaturaga is the highest indigenous political body, comprising representatives of Fiji's hereditary hierarchy. Approximately 7,170 yavusa (tribal) and mataqali (clan) 
titleholders are represented in this body. ${ }^{1}$ In concert with the Native Land Trust Board, it controls 89-90 per cent of the land (this figure has increased with the return of Schedule A and B Crown lands). Of the 7,170 tribal and clan titles, 25 per cent remain vacant, not through lack of interest, but because of strongly contested clan views that, in former times, could only have been resolved by warfare. At the time of the 2006 election, these title vacancies included some of the highest in the land - for example, the Tui Kaba na Vunivalu of Bau and titular head of Kubuna (vacant since 1989), Na Ratu mai Verata and head of pre-contact Fiji (since 2001), Tui Nadi (covering the Nadi airport), Tui Ba of Nailaga and Tui Navitilevu of Rakiraki (the latter two covering the western cane belt), and the Tui Nayau and the concurrent title of Sau ni Vanua ko Lau, of the Lau group of islands. A successor to the late Roko Tui Dreketi title-holder was installed in early 2005, but the political ramifications of this appointment for the vanua and lotu (itself an important issue in the electoral contest in Rewa) appear unclear at this stage. These long-standing succession issues are embedded in indigenous Fijian society and frame Fiji's political history; they inform, fuel and shape local perspectives and national disputes.

Customary chiefs in Fiji do not necessarily win at the polls, but social ranking in local hierarchies can prove highly significant to the outcome of the elections. From the 1970s to the 1980s, politics was dominated by the Ratus, particularly the big four, Ratu Sir George Cakobau, Ratu Sir Edward Cakobau, Ratu Sir Kamisese Mara and Ratu Sir Penaia Ganilau. With the exception of Ratu Edward, all held vanua and matanitu titles. Ratu George held the Tui Kaba na Vunivalu titles of Kubuna, Ratu Penaia the Tui Cakau title of Tovata, Ratu Mara held the Tui Nayau and most senior title of Lau while his wife, Ro Lady Lala Mara, held the Roko Tui Dreketi title and paramountcy of the confederacy of Burebasaga.

In the 2006 election, leader of the National Alliance Party Ratu Epeli Ganilau, was the son of a former Tui Cakau and former president. Ratu Epeli was a candidate for the Tui Cakau title and is married to the daughter of former president Ratu Sir Kamisese Mara, but his party gained not a single seat. In contrast, his rival and successor to the Tui Cakau title, Ratu Naiqama Lalabalavu, who had formed the Conservative Alliance-Matanitu Vanua (CAMV) prior to the 2001 election, was elected and formed a coalition government with Lauan 
Prime Minister Qarase's Soqosoqo ni Duavata ni Lewenivanua (SDL) party. As the paramount titleholder of Tovata in the pre-Tui Lau Ma'afu period, an area which covers Qarase's constituency, Lalabalavu was immediately elevated to cabinet and appointed to the all-important land portfolio. During his term in office, he was charged and convicted for inciting a mutiny during the 2000 unrest in the Northern Division. After serving his sentence extramurally at the Nadera Catholic parish, he was reinstated to cabinet though not to the same portfolio. During the lead-up to the 2006 election, Lalabalavu disbanded the CAMV, joined the ruling SDL and was elected under the SDL ticket. In terms of traditional Fijian polities, Lalabalavu's membership of the SDL has considerably strengthened its position in northern Fiji.

Included among the SDL's senior party members are well-placed chiefs. As well as Ratu Naiqama (the Tui Cakau), they include Ratu Suliano Matanitobua (the Tui Namosi) and Ro Teimumu Kepa (recently appointed Roko Tui Dreketi). The Tui Cakau and Roko Tui Dreketi titles are the paramount positions in two of Fiji's three confederacies. The third confederacy, which was unrepresented at the parliamentary level, is Kubuna. The close association among the three ruling families made the absence of a direct representative of the Bau conspicuous in the parliament. This was redressed by nominations to the Senate. Soon after the 2006 election, the Prime Minister decided to appoint a member of the Vunivalu family to cabinet through the Senate. She is Adi Samanunu Cakobau-Talakuli, eldest daughter of the late Vunivalu, and one of the most eligible contenders for her father's title. In this way, it would appear, Qarase has galvanized Fijian support while forming a multiparty cabinet with the Fiji Labour Party (FLP).

How did customary chiefs fare as political candidates in the 2006 elections? From Table 20.1 it can be seen that the number of chiefs standing as political candidates increased by eight between 1999 and 2001, but decreased by 20 in 2006. The number of chiefs elected fell (by five) between 2001 and 1999, but increased (by four) between 2001 and 2006. However, while these figures show a declining number of chiefly candidates between 1999 and 2006, the decline is compensated for by the number of chiefs holding high titles among the elected candidates. In other words, chiefs vested with high titles, such as Tui Cakau and Roko Tui Dreketi, continued to be returned, while the 
Table 20.1 Performance of chiefly candidates in parliamentary elections

\begin{tabular}{lccccc}
$\begin{array}{l}\text { Election } \\
\text { year }\end{array}$ & $\begin{array}{c}\text { No. of candidates } \\
\text { standing in } 48 \\
\text { constituencies } \\
(23+25)\end{array}$ & $\begin{array}{c}\text { No. of candidates } \\
\text { known as } \\
\text { customary } \\
\text { chiefs }\end{array}$ & $\begin{array}{c}\text { No. of chiefly } \\
\text { candidates } \\
\text { expressed as } \\
\text { per cent of } \\
\text { total candidates }\end{array}$ & $\begin{array}{c}\text { No. of elected } \\
\text { chiefly } \\
\text { candidates }\end{array}$ & $\begin{array}{c}\text { No. of elected } \\
\text { chiefly candidates } \\
\text { expressed as } \\
\text { per cent of } \\
\text { total candidates }\end{array}$ \\
1999 & 240 & 30 & 12.5 & 12 & 5 \\
2001 & 256 & 38 & 15 & 7 & 3 \\
2006 & 247 & 18 & 7 & 11 & 4 \\
\hline
\end{tabular}

number of electorally successful chiefs with lesser vanua titles (or none at all) fell. The reason for the declining number of chiefs in national politics is not because of lack of Fijians' interest in their chiefs, but because of the intense competition among rival candidates for chiefly titles. Many of the title disputes are under investigation by the Native Lands and Fisheries Commission, and decisions on others are undergoing judicial review. Because of the intensity of competition, rival candidates and supporters have agreed to disagree, postpone an appointment and continue the discussion until a consensus has been reached. This was confirmed by a leading member of the mataqali Tui Kaba and former speaker of the House, Ratu Epeli Nailatikau: when asked whether the mataqali was losing interest in the leading title of Kubuna, he was adamant that there was no loss of interest. 'On the contrary', he said. 'as soon as the election and the Methodist conference are over, we will meet to settle it. It is largely an internal family dispute'. ${ }^{2}$

\section{Limitations in identifying who is and who is not a chief}

While some chiefs indicate their vanua status by prefacing their candidacy with the ratuladi/bulou/ro style of address, many do not. Many enter the election without chiefly style, but, once they enter parliament, a chiefly style suddenly appears, conferred either by themselves or by someone else. In theory, it should be possible to identify a Fijian chief by the style of address used during the election campaign: ratu for men, adi and bulou for women and ro in Rewa for either gender. But identifying who is and who is not a chief at elections 
is a complicated matter. In this regard, two kinds of chiefs are distinguished: one who inherits a chiefly style by birth, and the other who is a chief by birth and by appointment and installation to one of various offices within the vanua. Normally accompanied by ceremony, such offices include na turaga na mataqali, yavusa, tikina, vanua or a matanitu. Another term signifying a chief is apparent in kin relationship. Between equals, relations are usually conducted on a first-name basis, but between unequals, or those acknowledged as lower position or younger, use of ratuladi/bulou/ro styles of address often punctuates the conversation. Identifying election candidates who are chiefly is particularly difficult in Fijian elections because, unlike Samoa or Tonga, Fiji has electoral regulations that do not distinguish between chiefs and non-chiefs.

Was there a discernible pattern in the number of chiefly candidates and elected chiefly candidates over these past three elections? The following analysis focuses on candidates whose chiefly rank is clearly established.

\section{Chiefs in the 1999 election}

In 1999, there were 30 candidates of known chiefly rank out of the 240 candidates from the 48 constituencies in which Fijians can stand (23 Fijian and 25 Open). Of these, 12 , or 5 per cent of the 240 candidates, were elected. Among the casualty list were important chiefs of vanua and yavusalmataqali, and siblings of vanua and matanitu chiefs. One vanua chief who lost was Ratu Tevita Bolobolo, holder of $\mathrm{Na}$ Tuvitilevu title and paramountcy of Ra. His defeat was doubly humiliating because he is a paramount titleholder. Moreover, his defeat was at the hands of Fiji-Indian candidates. In the first count, Ratu Bolobolo lost out to the Fiji Labour Party (FLP) candidate Sanjeet Chand Maharaj, and, when the count went to preferences, he lost to independent candidate George Shiu Raj. Another paramount titleholder who failed to secure a seat was the $\mathrm{Na}$ Ka Levu of Nadroga. Contesting the Nadroga Open constituency, Ratu Sakiusa Makutu polled the largest number of votes on the first count. However, he failed to secure a simple majority and, when the count went to preferences, he was beaten by the FLP candidate, a chief of lower rank, Ratu Mosese Volavola. Other casualties included: the children of Fijis former Governor General and Vunivalu of Bau, Adi Litia Cakobau (Tailevu North/Ovalau Open) and Ratu Epenisa Cakobau (Tailevu South/Lomaiviti Open); the son of a former 
president and Tui Cakau, Ratu Epeli Gavidi Ganilau; the sister of former president and Tui Nayau, Adi Senimili Tuivanuavou (Lau/Taveuni/Rotuma); and Ratu Kamisese Mara’s brother-in-law, Ratu Tu'uakitau Cokanauto (Tailevu North/Ovalau Open). ${ }^{3}$

Of the twelve winning chiefly candidates, nine were in government and three in the Opposition. In government were: Koila Nailatikau-Mara (Veitokani ni Lewenivanua Vakarisito); Esira Rabuno (Fijian Association Party (FAP)); Isimeli Jale Cokanasiga; Isireli Vuibau (FLP); Tu’uakitau Cokanauto (FAP); Tevita Moemoedonu (FLP); Mosese Volavola (FLP); Kuini Vuikaba-Speed (FAP); and Ema Tagicakibau (FAP). In opposition were Kinijoji Maivalili, Inoke Kubuabola, and Naiqama Tawake Lalabalavu.

The opposition had higher-ranking chiefs than the government. One was the head of a matanitu, Tovata, and the other two were leading members of leading clans of the leading province within Tovata. Ratu Inoke Kubuabola is a member of the important 'Ai Sokula clan, and Ratu Kinijioji Maivalili is the heir apparent to the Tui Wailevu and Vunivalu titles of Wailevu; both have close ties to the 'Ai Sokula. The Tovata number was strengthened when another Cakaudrove chief from Natewa entered parliament. Former prime minister Sitiveni Rabuka resigned from his Cakaudrove West Open seat, and was replaced by Ratu Rakuita Vakalalabure, contender for the Vunivalu of Natewa title.

While the government side had nine ratus and adis, and represented all three matanitus (Kubuna, Tovata and Burebasaga), they were clearly not of the same ranking. Adi Koila Nailatikau Mara's mother and father covered both Burebasaga and Tovata, and her husband, the former Fiji Military Forces commander, former ambassador to the United Kingdom, roving ambassador to the Pacific region, and former Speaker of the House, covered Kubuna. Adi Kuini Speed was Tui Noikoro, a vanua chief in Navosa. Because Navosa had been marginalized due to its resistance to colonial authority, it did not have the same clout as other vanuas. Ratu Tu'uakitau Cokanauto is from the Tui Kaba and king-making clan of the Vunivalu of Bau, but he was not from the dominant household, the Mataiwelagi. Similarly, Ratu Tevita Moemoedonu and Ratu Mosese Volavola were not holders of vanua titles, and so did not have the same standing as the others within the vanua and matanitu. 
In terms of the Fijian hierarchy's support for the Labour coalition government, only Adi Lady Lala Mara, as the Roko Tui Dreketi, could be counted upon. Her daughter and a collateral cousin (who was also her brother-in-law) were members of the FLP coalition government. The other paramount chief, Tui Cakau, was in opposition, and the leading siblings of the other matanitu, Kubuna, from the competing sides of the Mataiwelagi household, each failed to secure a seat.

\section{Chiefs in the 2001 election}

In 2001, 38 candidates of known chiefly rank were amongst the 256 candidates that stood in the 48 constituencies (up from 30 candidates in 1999). Out of 38, only seven, or 3 per cent of the total number of candidates, won - considerably down from 1999. The successful chiefly candidates were:

- Ratu Suliano Matanitobua (SDL)

- Ro Teimumu Vuikaba Tuisawau Kepa (SDL)

- Ratu Jone Yavala Kubuabola (SDL)

- Adi Asenaca Caucau (SDL)

- Ratu Naiqama Tawake Lalabalavu (CAMV)

- Ratu Rakuita Saurara Vakalalabure (CAMV)

- Ratu Savenaca Draunidalo (independent - and heir apparent to the Tui Moala title).

The only survivor from the 1999 election was Ratu Lalabalavu, who was then in the opposition; once the two parties joined in coalition, he was given the lands portfolio. Unlike the 1999 election, the 2001 'casualty list' did not include a high number of significant vanua or yavusa chiefs, or their siblings. The losses included two vanua chiefs: Ratu Kinijioji Maivalili, heir apparent to the Tui Wailevu title; and Ratu Aisea Katonivere, the then heir apparent to the Tui Macuata title. The other losses include chiefs of secondary ranking, such as Bauans like Ratu Tu'uakitau Cokanauto, Adi Finau Tabakaucoro and Ratu Timoci Tavanavanua, Rewans like Ro Alipate Doviverata Mataitini, and Cakaudrovens like Ratu Aisake Kubuabola and Adi Ema Tagicakibau, the latter four contesting in constituencies outside areas of their chiefly standing. In doing so, it was commonly observed, many chiefs did not style themselves as ratus/adis. 
Of the seven chiefly candidates who were elected, four were from SDL, two were CAMV and one was an independent. None belonged to the FLP. The two CAMV chiefs and the independent chief joined the SDL-led coalition government, two in cabinet and one as Deputy Speaker. As for the opposition, the only support they could count on from chiefs came from those in the Great Council of Chiefs and the Senate. But they were very few, the notable one being the Tui Ba-i-Bulu, Ratu Sairusi Nagagavoka, who wielded considerable influence over his Party of National Unity from inside the Great Council of Chiefs.

\section{Chiefs in the 2006 election}

In 2006, the total number of candidates that stood for the 48 constituencies was 247. The number of candidates of known chiefly rank that stood for election dropped from 38 in 2001 to just 18. Of those 18, only 11, or just 4 per cent of all the candidates in the 48 constituencies, were elected.

The 11 chiefly candidates that were elected, all SDL members, were Ratu Isikeli Tasere, Ratu Suliano Matanitobua, Ro Teimumu Kepa-Tuisawau, Ratu Meli Saukuru, Ratu Naiqama Lalabalavu, Ratu Jone Y Kubuabola, Ratu Jone Waqairatu, Adi Asenaca Caucau-Filipe, Ratu Josefa Dimuri, Ratu Osea Vakalalabure and Ratu Savenaca Draunidalo.

Candidates of chiefly rank were not conspicuous among the FLP's newly elected Fijian MPs. After the election, a new female member with an impressive majority from the Yasawa Nawaka Open constituency, Adi Sivia Qoro, appeared in the FLP line-up for the multiparty cabinet and was given the commerce portfolio. Adi Sivia is from Naviti island in the Yasawas. Her mother, Adi Titilia, is Tui Marou and she herself is vasu to Marou village on Naviti, where she grew up. ${ }^{4}$ Overall, though, the overwhelming Fijian support in parliament firmly lies with the SDL government.

How representative is the SDL government of Fijian confederacies? Two vanualmatanitu titleholders are included, those of Burebasaga and Tovata through Ro Teimumu Kepa-Tuisawau and Ratu Lalabalavu, respectively. The only other vanua chief who stood and was elected was Ratu Suliano Matanitobua, the Tui Namosi, and representing the vanua of Serua and Namosi. Nadroga/Navosa is represented through Ratu Isikelu Tasere, Nadi-Ba-Tavua through Ratu Meli Saukuru. In addition to the Tui Cakau, the representation 
of Tovata is strengthened by Ratu Savenaca Draunidalo (Tui Moala of Yasayasa Moala), Ratu Josefa Dimuri of Bua/Macuata, and Natewan chief Ratu Osea Vakalalabure, and non-resident Cakaudrove chiefs, such as the powerful finance minister, Ratu Jone Yavala Kubuabola. A potential Tovata ally was Ratu Jone Waqairatu, a Lauan from Yaroi in Yasayasa Moala, who stood and was elected to the Tamavua/Laucala Communal constituency. ${ }^{5}$ (Ratu Draunidalo is an example of an urbane category of chiefs who consistently spurn being styled a ratu; on every occasion that I have met him his outstretched hand has always been accompanied by just 'Bula, Save'.)

The sole elected chiefly representative from Kubuna was Adi Asenaca Caucau-Filipe. The scarcity of Kubuna's presence in the Lower House and the conspicuous absence of a Cakobau descendant was addressed by a Senate appointment. After the 2001 election, the failure of any of Ratu George Cakobau's children (Adi Litia, Ratu Jioji and Ratu Tanoa Visawaqa) in elections was compensated for by the appointment of three Cakobaus at different times to Senate. In the 2006 election, none of the children contested and, in order to maintain a balance of representation at the parliamentary level, Prime Minister Qarase appointed the former ambassador to Malaysia, Adi Samanunu Cakobau-Talakuli, to cabinet as Minister of State through the Senate. With her appointment to cabinet, the SDL/FLP multiparty cabinet has representation from all of Fijis 19th century confederacies.

While the number of chiefly and successful candidates has decreased, those elected constitute a strong representation of Fijian vanua interests and hierarchy. In other words, while the overall number has decreased, the 'quality' of representation at the highest level has remained constant - an indication of the tenacity of the indigenous hold to nineteenth century governance structure.

\section{Conclusion}

In contemporary politics, succession struggles over vanua chiefly titles continue to plague current indigenous leadership. One striking theme from recent elections has been the consequence of the absence of leadership from Kubuna, particularly the mataqali of Tui Kaba. 'Because of the longstanding vacancy [in Kubuna], ...you cannot expect mana to flow down to the minor chiefs when there is no one holding that powerful position. ${ }^{6}$ Vacant since 1989, 
the title of Vunivalu of Bau has generated a long-standing power struggle within the mataqali Tui Kaba, centred on the Mataiwelagi household, Ratu George Cakobau's household. Failure to resolve this indigenous issue has, I suggest, contributed to the events which brought Fiji to its knees in 2000. The consequences include pitting close siblings against each other in the 1999 election (consider the Tailevu North/Ovalau Open contest between Litia Cakobau of Mataiwelagi and collateral cousin Tu'uakitau Cokanauto of Naisogolaca). The split resulted in a victory for FLP candidate Ratu Isireli Vuibau, who did not command the same level of status within indigenous leadership. When the 2001 and 2006 elections were held, not a single member of the mataqali Tui Kaba stood, reflecting the unresolved leadership struggle. The Mataiwelagi family squabble within the Tui Kaba is just the tip of a growing iceberg. Figures released by the Native Land and Fisheries Commission in 2004 show the increasing number of vacant vanualyavusal tikinalmataqali titles. Such vacancies result in power vacuums all over Fiji at the local level. ${ }^{7}$ If the local leadership issues are not addressed, the Great Council of Chiefs and its associate arms, as a conglomerate institution of indigenous authority, risks becoming a refuge for unelected customary chiefs. The Council has already been labelled an anachronism by some observers, including Fijians. The all-too-familiar pattern that emerges is the use of both the Council and the Senate as havens for failed politicians of chiefly rank.

General elections provide an important indicator of the state of health of Fiji's chiefly institution. It has been a long-standing assumption that titled candidates such as chiefs have better chances of getting into parliament. The outcome of the past three elections disproves this. Titleholders who rely solely on ancestry are unlikely to fare well in politics. Higher levels of education and professional experience in the modern globalized world and selective church engagement are increasingly more important. Political aspirants of hereditary stock may display their titles in preference to qualification and experience, but most voters will judge them by their performance. This is a trend that is likely to continue, in line with contemporary politics in Samoa and Tonga. 


\section{Notes}

1 Lewa, S. 'Confusion over chiefly titles', The Fiji Times, 26 October 2004.

2 Ratu Epeli Nailatikau, pers. comm., 30 April 2006.

3 Ratu Tu'uakitau later won the Tailevu North/Ovalau seat after the court overturned the earlier result because of an error in the way preferences were summed.

4 Apolosi Bose and Jon Fraenkel, pers. comm. 18 August 2006.

5 Adi Ema Tagicakibau, pers. comm. July 2006.

6 Ratu Sakiusa Matuku in The Fiji Times, 6 September 2004.

7 Lewa, S. 'Confusion over chiefly titles', The Fiji Times, 26 October 2004. 